\title{
Szennyvíziszap-kezelés hatása egy étkezési szárazbabfajta (Phaseolus vulgaris L.) növekedésére és rizoszférájának mikrobiális változására
}

\author{
${ }^{1}$ ABDORHIM HAMED, ${ }^{1}$ BAYOUMI HAMUDA E. A. F. HOSAM, ${ }^{1}$ KHALIF A. \\ ABDOUSSALAM, ${ }^{2}$ OLDAL BÁLINT, ${ }^{1}$ KECSKÉS MIHÁLY és ${ }^{1}$ HELTAI GYÖRGY \\ ${ }^{1}$ Szent István Egyetem, Környezettudományi Doktori Iskola, Gödöllő-Budapest és \\ ${ }^{2}$ MTA Talajtani és Agrokémiai Kutatóintézet, Budapest
}

A kommunális szennyvíziszap talaj-növény rendszerben történő hasznosítását széles körben az elhelyezés egy lehetséges módszereként tartják számon (ANTON \& ANTAL, 1987; EC, 1999a,b). A szennyvíziszapok esszenciális növényi tápanyagokat, a talaj termőképességét növelő szerves anyagokat, valamint a növények szempontjából hasznos mikroorganizmusokat is tartalmaznak. Ez pedig szükségessé teszi a növény-talaj rendszerekre kifejtett hatások pontosabb, körültekintőbb vizsgálatát, tekintettel pl. a rendszeres kihelyezés talajmikrobák müködőképességére kifejtett negatív hatására, mely a talajban feldúsuló nehézfémek miatt (BIRÓ, 1999; BIRÓ et al., 2004; SASTRE et al., 1996) léphet fel. Az emberi egészség védelme érdekében (DUMONTET et al., 1999) a kijuttatás során a növénytermesztés szempontjából hasznos mikrobákkal való felülkezelési lehetőségekkel (KöDÖвÖCZ et al., 2003), vagy a nehézfémek táplálékláncban történő akkumulációjával is számolni kell (ANTON et al., 1994; KÁDÁR, 1995).

A biztonságos kihelyezés érdekében tehát sürgető az olyan alternatív technológiák kifejlesztése, amelynek eredményeképpen mikrobiológiai szempontból stabil, kórokozóktól mentes, a szerves anyagokat már lebontott formában, illetve a környezetvédelmi határértékeknek megfelelö felvehető nehézfémet tartalmazó iszapot használunk fel (ANTAL et al., 1988). A nehézfémek növényekre kifejtett káros hatásai kialakulásában a fiziológiai tulajdonságok (CSATHÓ, 1994; KERESZTÚRI et al., 2003) mellett a szennyezés típusa (NÉMETH et al., 1993), a talajok fizikai-kémiai állapota [pl. pH-ja és/vagy szervesanyag-tartalma (LEHOCZKY et al., 1997; ANTON et al., 2004)], illetve a kihelyezési dózisok játszanak elsősorban szerepet. A talaj- és rizobiológiai tulajdonságok kedvezőtlen megváltozása ugyancsak ismert (BIRÓ, 2004); mindezek a fitoremediációs növényoltásos technikák gyors elterjedését eredményezték az utóbbi időben (MÁTHÉ et al., 2004; MÁTHÉNÉ \& ANTON, 2004; VIVAS et al., 2004).

A talaj tápanyagforgalmát a fizikai, kémiai paraméterek, valamint a növénytakaró és a mikrobiális tevékenység mellett a szabad, még inkább az akkumulált enzimfrakciók (pl. agyagásványok kristályrácsaiban) aktivitása is meghatározza

Postai cím: HOSAM E. A. F. BAYOUMI HAMUDA, Szent István Egyetem Környezettudományi Doktori Iskola, 1111 Budapest, Budafoki út 59.E-mail: titkar@mpv.ph.hu 
(ANTON, 1985). Az akkumulált enzimfrakció aktivitását akkor is megtarthatja, ha a talaj mikrobiális tevékenysége, illetve növénytakarója megszünik. Az akkumulált frakción belül az immobilizált enzimek kémiailag kötötten védve vannak a denaturációval szemben, melyet modellkísérletben (MÁTHÉ et al., 1994) is kimutattak.

Korábbi munkánk során a növényi gyökérrendszer müködőképességében bekövetkezett változásokat kísértük figyelemmel fiziológiai, mikrobiológiai és biokémiai állapotjelzők segítségével a növény-talaj rendszerben, tavaszi búza jelzőnövénnyel (ABDORHIM et al., 2004). Most viszont - meghagyva az elözö közlemény gondolatmenetét - étkezési szárazbabfajtával végzett kísérleteinkben foglaljuk öszsze a fokozatosan növekvő kommunális szennyvíziszap-adagok hatását.

\section{Anyag és módszer}

Talaj és szennyviziszap. - A kísérletekben használt talaj a Debreceni Egyetem, Agrártudományi Centrum Nyíregyházi Kutatóközpont üzemi területéről származott. E gyengén savanyú kémhatású, humuszos homoktalaj (Lamellic Arenosol; WRB, 1998) csekély mésztartalmú és kis természetes vízkapacitású. Fontosabb jellemzői a következök: $\mathrm{pH}\left(\mathrm{H}_{2} \mathrm{O}\right)$ : 5,92; összes-só: $0,17 \%$; $\mathrm{CaCO}_{3}$ : 3,1\%; humusz: $2,54 \%$ (mind tömegszázalék). A meghatározó makro- és mikroelemek között a $\mathrm{NO}_{3}-\mathrm{N}-$ 23,0 ; a $\mathrm{Zn}-1,7$; a Cu- 1,4; ill. a Mn-tartalom $55,0 \mathrm{mg} \cdot \mathrm{kg}^{-1}$ légszáraz talajra vonatkoztatva.

Az aerob úton digerált szennyvíziszap Nyíregyházáról, háztartási szennyvizet tisztító szennyvíztelepről került begyüjtésre. A szennyvíziszap összetétele $\left(\mathrm{mg} \cdot \mathrm{kg}^{-1}\right.$ szárazanyag): As: 0,45; Ca: 21303; Cd: 2,30; Cr: 17,30; Cu: 110,4; Fe: 11308; Hg: 1,82; K: 1716; Mg: 2507; Mn: 421,0; összes N: 7470; Na: 994,0; Ni: 21,60; összes P: 8720; Pb: 66,90 és $\mathrm{Zn}$ : 537,0. Az összes szárazanyag-tartalom 53\% (tömegszázalék), míg az iszap kémhatása $\mathrm{pH}\left(\mathrm{H}_{2} \mathrm{O}\right) 6,9$ volt.

A légszáraz talajt a szennyvíziszappal alaposan összekevertük oly módon, hogy a kész keverék rendre a következö tömegszázalékokban tartalmazzon szennyvíziszapot: 0 (iszapmentes kontrolltalaj), 10, 20, 30, 40, 50, 60, 70, 80, 90, valamint $100 \%$ (csak szennyvíziszap, talaj nélkül).

A növénynövekedésre gyakorolt hatás vizsgálata. - Tesztnövényként a Magyarország eltérö ökológiai adottságú területein is biztonsággal termeszthető, környezeti tényezőkkel és betegségekkel szemben ellenálló, stressz hatása alatt is nagy zöldtömeget adó (KHALIF et al., nem hivatkozott tapasztalat) Albamax étkezési szárazbabfajtát (Phaseolus vulgaris L.) választottuk. 5 szem felületén sterilizált bab magot ültettünk a fentiek szerint előkészített $2 \mathrm{~kg}$-os müanyag edényekbe. Hét napig történő csíráztatás után a fiatal növényeket 3 növény/edény sürüségüre ritkítottuk. A növények relatív száraz tömegét (NRSzT) és szár/gyökér (Sz/Gy) arányukat 50 napig tartó nevelést követően határoztuk meg $\left(75^{\circ} \mathrm{C}\right.$ hömérsékleten, szárítószekrényben, tömegállandóságig szárítva). 
Talaj-mikroorganizmusok elöfordulása. - A növényekröl leválasztott gyökereket folyó csapvízben mostuk a rátapadó talajszemcsék eltávolítása érdekében, melyet $0,85 \%$ sótartalmú vízzel történő újabb mosás követett. A gyökerekből $1 \mathrm{~g}$ mennyiséget felaprítottunk, majd $9 \mathrm{ml}$ fiziológiás sóoldattal maceráltunk. A szuszpenzióból steril csapvízzel hígítási sort készítettünk. A rizoszférában előforduló összes aerob mikrobaszámot, az aerob spóraképzők, az aktinomiceták és a mikroszkopikus gombák számát szelektív táplemezek felhasználásával határoztuk meg SZEGI (1979) és ANGERER és munkatársai (1998) módszere szerint. Ennek során a mintákból 0,1-0,1 ml-eket szélesztettünk King-B, Pseudosel, Nutrient, triptonglükóz-élesztőkivonat, Martin, malátakivonat, Jensen, valamint Küster-Williams szilárd táptalajokra. A különböző táptalajokon történt tenyésztés során Pseudomonas, Bacillus faj-reprezentánsokat, illetve spóraképző baktériumokat, mikroszkopikus gombákat (pl. élesztök, és Trichoderma sp.), valamint aktinomicetákat is izoláltunk. Az agarlemezeket a mikrobák típusának megfelelően 28,30 , ill. $37^{\circ} \mathrm{C}$ on inkubáltuk 2-7 napig. Az izolátumok meghatározása érdekében Gram-festést és különbözö biokémiai teszteket hajtottunk végre (BERGEY's Manual of Systematic Bacteriology, 1984), valamint felvettük a sejtmorfológiai jellemzőket a NAUTIYAL és DION (1990) által leírtak szerint. A baktérium izolátumokat BBL Crisystal ${ }^{\mathrm{TM}}$ módszerrel határoztuk meg.

Az enzimaktivitások alakulása. - A dehidrogenázaktivitást GARCÍA és munkatársai (1993) módszere alapján mértük (az adatokat $\mu \mathrm{g} \mathrm{INTF \cdot g}{ }^{-1}$ száraz talaj dimenzióban fejeztük ki). A katalázaktivitás megállapítása a kálium-permanganátos oxigénfogyasztás révén történt, hidrogén-peroxid $\left(\mathrm{H}_{2} \mathrm{O}_{2}\right)$ hozzáadást követően (TABATABAI \& BREMNER, 1970) $\left(\mu \mathrm{mol} \mathrm{O}_{2} \cdot\right.$ perc $^{-1} \cdot \mathrm{g}^{-1}$ száraz talaj). Az ureáz- és proteázaktivitás mérése NANNIPIERI és munkatársai $(1980)\left(\mu \mathrm{mol} \mathrm{NH}{ }_{4}^{+}-\mathrm{N} \cdot \mathrm{g}^{-1}\right.$ száraz talaj $\left.\cdot \mathrm{h}^{-1}\right)$; a foszfatázaktivitás TABATABAI és BREMNER $(1969)(\mu \mathrm{mol}$ P-nitrofenol (PNP) $\cdot \mathrm{g}^{-1}$ száraz talaj $\left.\cdot \mathrm{h}^{-1}\right)$; a $\beta$-glükozidáz-aktivitás meghatározása a MASCIANDARO és munkatársai (1994) ( $\mu \mathrm{mol}$ P-nitrofenol (PNP) $\cdot \mathrm{g}^{-1}$ száraz talaj· $\left.\mathrm{h}^{-1}\right)$ által leírt módszerrel történt.

Statisztikai analizis. - A kísérletet teljes véletlen blokk elrendezésben, három párhuzamos vizsgálatban, három ismétléssel állítottuk be. Az eredményeket a relatív növénynövekedés (\%) esetében a kezeletlen kontroll százalékában fejeztük ki. A kezelések közötti statisztikailag igazolható eltérések kiszámításához egyszeres osztályozásra épülő varianciaanalízist (ANOVA) használtunk. A szignifikáns differenciát $\mathrm{P} \leq 0,05$ szinten számítottuk ki.

\section{Eredmények}

A szennyviziszap-adagok hatása a növénynövekedésre

Az 1. ábra a növekvő szennyvíziszap-adagokkal kezelt talajokban nevelt bab egész növényre vonatkozó relatív száraz tömegeit (NRSzT) mutatja be; ahol a legmagasabb értéket a 70/30 és 80/20 iszap/talaj aránynál kaptuk, de szignifikánsan 


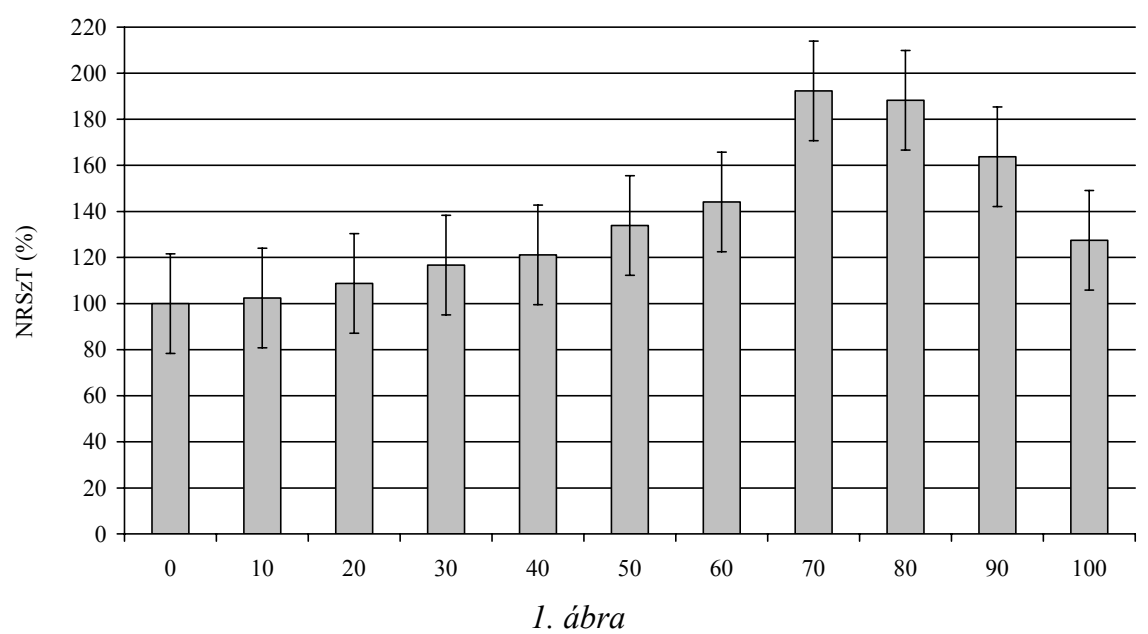

A szennyvíziszappal kezelt gyengén savanyú humuszos homoktalajban 50 napon keresztül nevelt babnövények relatív száraz tömegének (NRSzT) alakulása; a függőleges vonások a $\mathrm{SzD}(\mathrm{P} \leq 0,05)=21,63$ mértékét jelzik. Vízszintes tengely: az iszap-talaj keverék aránya, \%

nagyobb növénytömeg jelentkezett a 60 és $90 \%$-os iszapmennyiségek alkalmazásával is. Ily módon az optimális keverék alkalmazásával a növénytömeg akár duplájára is növelhető. A $10-50 \%$ és a $100 \%$ értékek között a bab relatív száraz tömegében a kontrollhoz képest szignifikáns különbség nem adódott.

Az iszapmennyiségeknek a szár/gyökér (Sz/Gy) arányra gyakorolt hatása 10 és $50 \%$ közötti iszapadagok esetén nem mutatott nagy eltéréseket. A maximális arányt

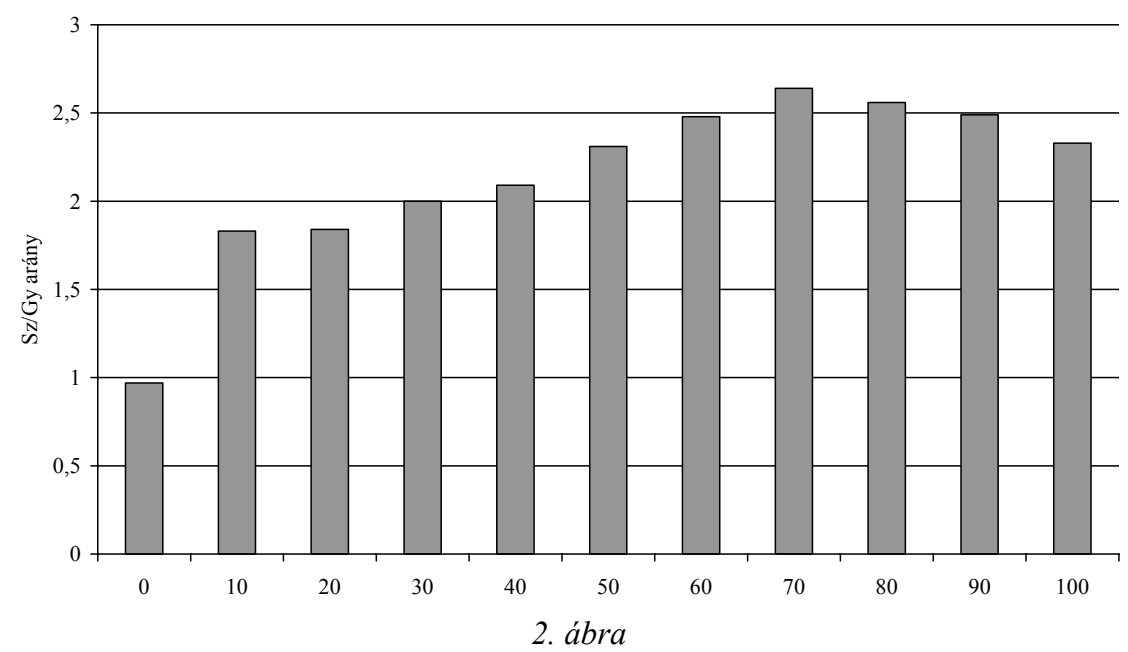

A szennyvíziszappal kezelt gyengén savanyú humuszos homoktalajban 50 napon keresztül nevelt babnövények szár/gyökér ( $\mathrm{Sz} / \mathrm{Gy})$ arányának alakulása; $\mathrm{SzD}(\mathrm{P} \leq 0,05)=0,77$. Vízszintes tengely: az iszap-talaj keverék aránya, $\%$ 
ebben az esetben is az iszappal 70 és $80 \%$-ban kezelt talajnál kaptuk (2. ábra). Az ilyen jelentős mennyiségü szervesanyag-bevitellel a babnövények hajtástömege két és félszerese lett a tenyészedényekben mért gyökértömegeknek.

\section{A mikrobiális tulajdonságok alakulása}

Laboratóriumi körülmények között a növekvő szennyvíziszap-adagoknak a talaj-mikroorganizmus csoportok összetételére gyakorolt hatásait is tanulmányoztuk. A bab gyökérrendszerében a leggyakoribb mikroszkopikus gombaképviselök az Alternaria, Aspergillus (A. niger, A. flavus és A. wentii); Cladosporium sp., Fusarium sp. (F. oxysporum, F. solani); Mucor, Penicillium (P. chrysogenum, P. notatum, $P$. stoloniferum), Rhizopus nigricans és Trichoderma (T. harzianum, $T$. viride, T. koningii) nemzetség képviselői bizonyultak az iszapadagokkal növekvő mértékben. Az aktinomicetákat a Streptomyces génusz tagjai képviselték.

Az 1. táblázatban szereplő eredmények a teljes mikrobiológiai összetételböl a spóraképző baktériumok, aktinomiceták és gombák számát mutatják a babnövény rizoszférájában. A mikroorganizmusok tömege $\mathrm{P}<0,05$ szinten szignifikáns mértékben megnőtt, ha a rizoszféra talaja $30 \%$ és $100 \%$ közötti szennyvíziszap-adagokat tartalmazott. Az iszapmennyiségek növelésével a mikrobaszám is párhuzamosan emelkedett. A szennyvíziszapok rövid idejü alkalmazásánál ennek megfelelöen a mikrobák számára hozzáférhető szubsztrátok mennyiségének növekedésén túl - elsősorban a talaj-növény rendszerekben - a növény a javuló tápelemfelvétel kedvező hatása miatt több mikroorganizmust is tud vonzani a gyökér környezetébe.

\section{1. táblázat}

A szennyvíziszappal kezelt gyengén savanyú humuszos homoktalajban 50 napon keresztül nevelt bab rizoszférájában előforduló főbb mikrobaképviselők biomasszájának alakulása

\begin{tabular}{|c|c|c|c|c|}
\hline $\begin{array}{c}(1) \\
\text { Kezelés } \\
\begin{array}{c}\text { iszapmennyiség, } \\
\mathrm{m} / \mathrm{m} \%)\end{array}\end{array}$ & $\begin{array}{c}(3) \\
\text { Baktériumok } \\
\left(\times 10^{6}\right)\end{array}$ & $\begin{array}{c}(2) \text { Átlagérték/g talaj } \\
\text { Aerob spóraképző } \\
\text { baktériumok }\left(\times 10^{3}\right)\end{array}$ & $\begin{array}{c}(5) \\
\text { Aktinomiceták } \\
\left(\times 10^{3}\right)\end{array}$ & $\begin{array}{c}(6) \\
\text { Gombák } \\
\left(\times 10^{4}\right)\end{array}$ \\
\hline 0 & 66 & 9,3 & 1,7 & 5,2 \\
10 & 117 & 11,2 & 2,8 & 6,1 \\
20 & 167 & 12,7 & 3,1 & 7,3 \\
30 & $215^{*}$ & $14,6^{*}$ & $3,3^{*}$ & $7,7^{*}$ \\
40 & $249^{*}$ & $17,1^{*}$ & $3,9^{*}$ & $8,9^{*}$ \\
50 & $279^{*}$ & $20,4^{*}$ & $4,2^{*}$ & $10,3^{*}$ \\
60 & $312^{*}$ & $21,2^{*}$ & $4,8^{*}$ & $11,7^{*}$ \\
70 & $384^{*}$ & $23,4^{*}$ & $5,3^{*}$ & $12,9^{*}$ \\
80 & $452^{*}$ & $26,1^{*}$ & $5,6^{*}$ & $17,1^{*}$ \\
90 & $491^{*}$ & $33,3^{*}$ & $6,1^{*}$ & $18,3^{*}$ \\
100 & $543^{*}$ & $35,2^{*}$ & $6,3^{*}$ & $18,5^{*}$ \\
a) $\mathrm{SzD}_{5 \%}$ & 103,81 & 5,28 & 0,99 & 2,47 \\
\hline
\end{tabular}

*: az értékek a kontrollhoz viszonyított szignifikáns különbséget $(\mathrm{P} \leq 0,05)$ jelölik 
A babnövény gümőképzése a gümőszám alapján a 20 és $40 \%$ iszapot tartalmazó keverékekben volt a legintenzívebb.

A bab gyökérrégiójában előforduló rizobaktériumok százalékos arányait vizsgálva megállapíthatjuk, hogy a Gram-negatív baktériumok között $(72,6 \%)$ a pálcika alakúak aránya 90,8\%, ezen belül a fluoreszcens Pseudomonasoké 36,4\%, a Rhizobium leguminosarum bv. phaseoli-é pedig 13,6\%-nak bizonyult. A BBL Crystal módszer segítségével Stenotrophomonas maltophilia képviselőket is találtunk, mely faj korábban a Pseudomonas nemzetségbe tartozott. Megtaláltuk az Enterobacter nemzetség néhány törzsét is, viszont Pseudomonas aeruginosa fajreprezentáns nem került elő. A nagyobb (70\%-tól) iszapadagok esetében a Burkholderia cepacia és Flavobacterium multivorum törzsek is gyakoriak voltak.

A Gram-pozitív $(27,4 \%)$ baktériumok esetében a pálcika alakúakon $(79,7 \%)$ belül az aerob spóraképző baktériumok $(88,2 \%)$ között a Bacillus sp. baktériumok bizonyultak a leggyakoribbnak (37,7\%). Ezeket mindegyik iszappal kezelt talajból sikerült izolálnunk. $40 \%$ iszaparánytól Bacillus mycoides, B. subtilis, Corynebacterium sp., Chromobacterium violaceum, Micrococcus luteus, Serratia marcescens egyre több törzsét izoláltuk. A rizoszférában a Gram-negatív és Grampozitív baktériumok aránya 2,65 volt.

\section{A különbözö enzimek aktivitásának alakulása}

A 2. táblázat az általunk vizsgált enzimaktivitások értékeit mutatja be. A mikrobaszámokhoz hasonló tendencia szerint az enzimaktivitások általában az iszap-

\section{2. táblázat}

A főbb enzimek aktivitása a szennyvíziszap-adagokkal kezelt gyengén savanyú humuszos homoktalajban nevelt babnövények rizoszférájában

\begin{tabular}{|c|c|c|c|c|c|c|}
\hline \multirow{3}{*}{$\begin{array}{c}\text { (1) } \\
\text { Kezelés } \\
\text { (iszap- } \\
\text { mennyiség, } \\
\% \text { ) }\end{array}$} & $\begin{array}{c}\text { (2) } \\
\text { Dehidro- } \\
\text { genáz- }\end{array}$ & $\begin{array}{c}(3) \\
\text { Kataláz- }\end{array}$ & $\begin{array}{c}\text { (4) } \\
\text { Proteáz- }\end{array}$ & $\begin{array}{c}(5) \\
\text { Ureáz- }\end{array}$ & $\begin{array}{c}\text { (6) } \\
\text { Foszfatáz- }\end{array}$ & $\begin{array}{c}(7) \\
\beta \text {-glü- } \\
\text { kozidáz }\end{array}$ \\
\hline & \multicolumn{6}{|c|}{ aktivitás ( $\mathrm{g}^{-1}$ talaj) } \\
\hline & $\mu \mathrm{g}$ INTF & $\mu \mathrm{mol} \mathrm{O}$ & \multicolumn{2}{|c|}{$\mu \mathrm{mol} \mathrm{NH}_{4}^{+}$} & \multicolumn{2}{|c|}{$\mu \mathrm{mol} \mathrm{PNP}$} \\
\hline 0 & 81 & 1,5 & 1,2 & 1,1 & 68 & 119 \\
\hline 10 & 95 & 1,9 & 1,6 & 1,2 & 79 & 131 \\
\hline 20 & 114 & $2,2 *$ & $1,9^{*}$ & 1,4 & $101^{*}$ & $149 *$ \\
\hline 30 & $154 *$ & $2,5^{*}$ & $2,1 *$ & $1,7 *$ & $106^{*}$ & $167^{*}$ \\
\hline 40 & $171^{*}$ & $2,8^{*}$ & $2,4^{*}$ & $2,1^{*}$ & $117^{*}$ & $181^{*}$ \\
\hline 50 & $191 *$ & $3,1^{*}$ & $2,8^{*}$ & $2,4^{*}$ & $135^{*}$ & $203^{*}$ \\
\hline 60 & $217^{*}$ & $3,6^{*}$ & $3,2 *$ & $2,7 *$ & $148 *$ & $217^{*}$ \\
\hline 70 & $293 *$ & $3,9 *$ & $3,7 *$ & $2,9 *$ & $193 *$ & $246^{*}$ \\
\hline 80 & $341^{*}$ & $4,4^{*}$ & $4,2 *$ & $3,1^{*}$ & $131^{*}$ & $189^{*}$ \\
\hline 90 & $188^{*}$ & $2,9 *$ & $3,1^{*}$ & $2,6^{*}$ & 88 & 147 \\
\hline 100 & $163^{*}$ & $2,4^{*}$ & $2,6^{*}$ & $1,9 *$ & 72 & 121 \\
\hline a) $\mathrm{SzD}_{5 \%}$ & 52,81 & 0,58 & 0,60 & 0,46 & 25,09 & 27,57 \\
\hline
\end{tabular}

Megjegyzés: lásd 1. táblázat 
adagok növelésével párhuzamosan fokozódtak. Eredményeink szerint 30\% és $80 \%$ közötti iszapadagolás esetében a kontrollhoz ( $0 \%$ iszap) viszonyított értékek egységesen szignifikánsnak bizonyultak $\mathrm{P}<0,05$ szinten. Sok esetben (a foszfatáz és a $\beta$-glükozidáz kivételével) 90 és $100 \%$ szennyvíziszap-adagolásnál is szignifikáns különbséget regisztrálhattunk.

Az egyes enzimek iszapadagolástól függő aktivitásait elemezve a következőket állapíthattuk meg. A dehidrogenázaktivitás a kontrollhoz képest $80 \%$ iszapadagolásnál volt a legnagyobb, de mindegyik koncentrációnál növekedett. A katalázaktivitás $20 \%$ és $80 \%$ iszaptartalom között úgyszintén növekvő értékeket mutatott. A maximális proteáz- és ureázaktivitás a $80 \%$ iszapot tartalmazó talajokban volt mérhető a növény rizoszférájában. A foszfatáz- és $\beta$-glükozidáz-aktivitás a $20-80 \%$ iszapdózis tartományában szignifikánsan volt nagyobb a kontrollnál. Mindkét enzim legnagyobb szignifikáns értékei az iszappal 70\%-ban kezelt talaj esetében adódtak.

\section{Az eredmények megvitatása}

A növénynövekedés tekintetében eredményeink alátámasztják KRAUSS és DIEZ (1997) tanulmányát, mely szerint a szennyvíziszap-eredetü nehézfémekkel 5 különböző szinten szennyezett homoktalajban nevelt növények morfológiai jegyei a kontrollhoz képest kifejezettebbek voltak. ELEIWA és munkatársai (1996) lóbab jelzönövénnyel a gümőszám, a növénymagasság, de még a levélfelület nagyságát is fokozni tudták kétféle kommunális szennyvíziszap alkalmazásával, melyet vizsgálatainkkal a babnövény esetében is igazoltunk. A szár/gyökér (Sz/Gy) arányok a különbözö talaj-iszap keverékek esetében az iszapadagok növelésével szintén megnövekedtek, még $100 \%$ iszap esetében is, bár ez utóbbi esetben a szignifikancia nem volt igazolható. A kezelt talajban nevelt növények Sz/Gy aránya a kontrollhoz képest nagyobb volt; azaz vizsgálatainkban a hajtás hossza és tömege is nagyobb volt a gyökér megfelelő adatainál. A növények növekedési erélye mellett egészségi állapotuk is jobb volt, mint a kontrollé. A növények tehát a közvetlen környezetből a könnyen felvehetö mikro-, illetve makro-tápanyagokat intenzíven hasznosították. A maximális szár/gyökér arányt és az egész növény legnagyobb relatív száraz tömegét TSADILAS és munkatársai (1995) eredményeivel ellentétben az iszappal 70 és 80\% mennyiségben kezelt talajnál kaptuk, ami azt bizonyítja, hogy az optimális iszapmennyiséget elsősorban az adott talajtípus és a termesztett növény befolyásolja.

A talaj mikroorganizmusai, leggyakrabban a gombák, baktériumok és aktinomiceták a talaj termékenységéhez számos módon hozzájárulnak. A mikroorganizmusok jelenléte és aktivitása ezért a mezőgazdasági talajok termékenysége szempontjából alapvető jelentőségủ. A trágyázásnak a talajok termékenységére kifejtett jótékony hatása régóta ismert. A szennyvíziszap-kezelések általában a talaj szervesanyag-tartalmának növelése révén fokozzák a talaj-mikroorganizmusok közösségeinek aktivitását (SEAKER \& SOPPER, 1988). Eredményeink összhangban vannak a fent említett munkákban közöltekkel, miszerint a talajhoz kevert iszap arányának növelésével a mikrobatömeg, így az általános mikrobiális és enzimaktivitás, ezzel párhuzamosan pedig a termékenység is megnő. 
A rövid távú kedvező hatásokon túl azonban tartós szennyvíziszap-kitettségek után számolnunk kell a nehézfémek károsító hatásaival is számos mikrobiológiai és biokémiai tulajdonság esetében. A tartós szennyvíziszap-kihelyezés ily módon csökkentheti a dehidrogenáz (REDDY \& FAZA, 1989), az ureáz és a foszfatáz (REDDY et al., 1987) aktivitását is, melyet eredményeink viszont csak a foszfatáz esetében támasztanak alá.

AICHBERGER és ÖHLINGER (1988) szerint ugyanakkor a dehidrogenáz és a proteáz aktivitása nehézfémmel szennyezett szennyvíziszap talajba történő adagolása során növekedett, melyet vizsgálatunkban is sikerült igazolni, hiszen e két enzim aktivitása még $100 \%$-os iszapadagok mellett sem csökkent szignifikáns mértékben. A szerzők szerint nem jelentkezett számottevő hatás a $\beta$-glükozidáz és az ureáz aktivitásában, ezeken kívül a foszfatáz aktivitása csak nagyon nagy arányú (90-100\%) iszapadagolás következtében csökkent. Eredményeink ellenben azt mutatják, hogy a $\beta$-glükozidáz és az ureáz aktivitása a 30-80\% iszapdózis-tartományban a kontrollhoz képest végig igazolhatóan növekedett. BROOKES és munkatársai (1984) szintén arról számolnak be, hogy az iszap kihelyezése során a talaj megnövekedett nehézfémtartalma ellenére a foszfatázaktivitás nem változott.

Eredményeink a fent idézettekkel csupán részben vannak összhangban, ami arra enged következtetni, hogy a hatás kifejeződésénél az iszap tulajdonságai mellett a talajkörülmények, a nehézfémek mibenléte és sajátságai, koncentrációja és hatóideje is fontos befolyásoló tényező lehet.

A szennyvíziszap kihelyezésével a mü- és szervestrágyázást részben helyettesítő, valamint a talaj fizikai-kémiai tulajdonságait is javító kezelés valósul meg, ami miatt az eljárás széles körben kerülhet gyakorlati alkalmazásra a mezőgazdaságban. A kihelyezésnél ugyanakkor az élelmiszerbiztonság szempontjai miatt folyamatos utómonitoring módszerek alkalmazása javasolt.

\section{Összefoglalás}

Tenyészedény-kísérletet folytattunk egy kommunális szennyvíziszap növénytalaj rendszerben való alkalmazási lehetőségeinek modellezésére egy Magyarországon köztermesztésben lévő, ellenálló étkezési szárazbabfajtával, mivel a szennyvíziszapok nagy tápelemtartalmuk miatt a növénytápláláshoz kedvezően járulhatnak hozzá.

Üvegházi modellkísérletben neveltünk ellenálló Albamax fajtájú étkezési szárazbab (Phaseolus vulgaris L.) növényeket; szennyvíziszapot különböző arányban tartalmazó talajkultúrákban, majd 50 napos tenyészidőszak után a talaj mikroorganizmus-közösségének állapotjelzőit elemeztük, az említett bab jelzőnövénnyel. Megállapítottuk, hogy az iszapadagolás minden esetben növelte a kontrollhoz képest az összes csíraszámot, különösen 30\% iszaptartalom felett. A kitenyészthető mikrobák között a rizoszférában minden szennyvíziszap-adagnál a baktériumok, különösen a Gram-negatív típusúak dominálták, mely jelenség azzal magyarázható, hogy e csoportban sok fermentatív (fakultatív anaerob) mikroszervezet fordul elö. Az iszapadagolás következtében megnőtt a redoxpotenciál és a hidrolitikus talajen- 
zimek aktivitása (dehidrogenáz, kataláz, proteáz, ureáz, $\beta$-glükozidáz és foszfatáz), $\mathrm{s}$ ezt a jelenlévő nehézfémek számottevően nem gátolták.

$\mathrm{Az}$ iszapkezelés kedvezően hatott a növények fejlödésére, különösen a magasabb iszapkoncentrációknál (70-80\%) nőtt meg a hajtás/gyökér arány, azaz fokozódott a zöldtömeg felhalmozása. Az iszapok rövid távú alkalmazásával ily módon a talaj termékenységére és fizikai, kémiai, valamint biológiai tulajdonságaira kedvezően ható módszerhez juthatunk.

Kulcsszavak: növényi növekedés, talajtermékenység, talajenzim-aktivitás, kitenyészthető mikroorganizmusok

\section{Irodalom}

ABDORHIM, H. et al., 2004. Szennyvíziszap-adagok hatása a növény (Triticum vulgare L.)-talaj rendszer néhány mikrobiológiai és biokémiai tulajdonságára. Agrokémia és Talajtan. 53. 355-366.

AICHBERGER, K. \& ÖHLINGER, R., 1988. Effects of sewage sludge and waste compost on some enzymatic activities tested in a field experiment. Poster paper. EC/EWPCA Symposium, Amsterdam.

ANGERER, I. P. et al., 1998. Indicator microbes of chlorsulfuron addition detected by a simplified soil dilution method. Agrokémia és Talajtan. 47. 297-304.

ANTAL, M. et al., 1988. Effect of C-sources and urea on the available N-content and urease activity of a calcareous sandy soil. Zentralbl. Mikrobiol. 143. 317-321.

ANTON A., 1985. Talajenzimek szerepe a talaj anyagforgalmi dinamikájában. Agrokémia és Talajtan. 34. 475-485.

ANTON, A. \& ANTAL, M., 1987. Effect of sewage sludge on saccharase activity of different soils. In: Proc. $9^{\text {th }}$ Int. Symp. on Soil Biology and Conservation of the Biosphere. 2. 771-776.

Anton, A., MÁthÉ, P. \& FÜLEKY, Gy., 2004. The effect of phosphorous fertilizer on the phosphomonoesterase activity of Capsicum annuum L. rhizosphere. Acta Microbiol. Immunol. Hung. 51. 196-197.

ANTON, A. et al., 1994. Effects of environmental factors and $\mathrm{Mn}, \mathrm{Zn}, \mathrm{Cu}$, trace elements on the soil phosphomonoesterase and amidase activity. Application of DISITOBI model. Acta Biol. Hung. 45. 39-50.

BergeY's Manual of Systematic Bacteriology, 1984. Vol. 1. (Eds.: KRIEG, N. R. \& HOLT, J. G.) Williams \& Wilkins. Baltimore-London.

BIRÓ B., 1999. További tudnivalók a kommunális szennyvíziszapok mezőgazdasági elhelyezéséről. Talajbiológiai következmények. Gyakorlati Agrofórum. (X.) 9. 4 6.

BIRÓ B., 2004. A növény-talaj-mikroba kölcsönhatások szerepe az elemfelvétel alakulásában. In: Mikroelemek a víz-üledék-mikroba-talaj-levegő-növény rendszerben. (Szerk.: SzILÁGYI M. \& SiMON L.) 1-12. Nyírség Nyomda. Nyíregyháza.

Biró, B., Morvai, B. \& ANTON, A., 2004. Limits of sewage sludge depositions of Hungarian soils, functioning of endosymbionts and phytoremediation possibilities. Acta Microbiol. Immunol. Hung. 51. 193-194. 
BROOKES, P. C. et al., 1984. Effects of heavy metals on microbial activity and biomass in field soils treated with sewage sludge. Environ. Contamin. Chem. 4. 574-583.

CSATHÓ P., 1994. A környezet nehézfém-szennyezése és a mezőgazdasági termelés. MTA TAKI-Akaprint. Budapest.

Dumontet, S., Dinel, H. \& BAlodA, S. B., 1999. Pathogen reduction in sewage sludge by composting and other biological treatments: a review. Biol. Agricult. Horticult. 16. 409-430.

EC, 1999a. Council directive 86/278/EEC of 12 June 1986 on the protection of the environment and in particular of the soil, when sewage sludge is being used for agriculture. Official Journal of the European Communities. L 181. 4/7/1999.

EC, 1999b. Council directive 1999/31/EC of 26 April 1999 on the landfill of waste. Official Journal of the European Communities. L. 182/1. 16/7/1999.

ELEIWA, M. E. et al., 1996. Influence of two sewage sludge sources on plant growth and nutrients uptake. Pakist. J. Sci. Indust. Res. 39. 34-37.

GARCÍA, C. et al., 1993. The dehydrogenase activity of soil as an ecological marker in processes of perturbed system regeneration. In: XI. Internat. Symp. Environmental Biogeochemistry, Salamanca, Spain. (Ed.: GALlARDO, G. F.) 89-100.

KÁDÁR I., 1995. A talaj-növény-állat-ember tápláléklánc szennyeződése kémiai elemekkel Magyarországon. Akaprint. Budapest.

KereszTúrI, P. et al., 2003. Evaluation of possibility of phytostabilisation of heavy metals by plants. Sci. Bullet. (Univ. Baia Mare) C.17. 243-247.

KÖDÖBÖCZ L. et al., 2003. Rhizobium törzsek túlélőképessége különböző vivőanyagokban. Agrokémia és Talajtan. 52. 395-408.

Krauss, M. \& DiEZ, T., 1997. Uptake of heavy metals by plants from highly contaminated soils. Agric. Res. 50. 343-349.

LEHOCZKY É., MARTH P. \& SzABADOS I., 1997. Meszezés hatásának tesztelése salátával nehézfém-szennyezett talajon. In: XI. Országos Környezetvédelmi Konferencia kiadványa. 196-200. Siófok.

Masciandaro, G., Ceccanti, B. \& GaracíA, C., 1994. Anaerobic digestion of straw and piggery wastewater. II. Optimalization of the process. Agrochimica. 38. 195 203.

MÁthé, P., FÜleKy, Gy. \& ANTON, A., 1994. Effect of carbon and phosphorus content on the phosphomonoesterase activity in soil. Acta Biol. Hung. 45. 81-85.

MÁthé, P., MÁthénÉ GÁspÁR, G. \& Anton, A., 2004. The phosphomonoesterase activity of lignite mine spoils. Acta Microbiol. Immunol. Hung. 51. 203-204.

MÁTHÉNÉ GÁSPÁR G. \& ANTON A., 2004. Toxikuselem-szennyeződés káros hatásainak mérséklése fitoremediációval. Agrokémia és Talajtan. 53. 413-432.

NANNIPIERI, P. et al., 1980. Extraction of phosphatase, urease, protease, organic carbon and nitrogen from soil. Soil Sci. Soc. Am. J. 44. 1011-1016.

NAUtiYAL, C. S. \& DiON, P., 1990. Characterization of opine-utilizing microflora associated with samples of soil and plants. Appl. Environ. Microbiol. 6. 25762579.

NÉMETH, T. et al., 1993. Fate and plant uptake of some heavy metals in soil-plant systems studied in soil monoliths. Agrokémia és Talajtan. 42. 195-206.

REDDY, G. B. \& FAZA, A., 1989. Dehydrogenase activity in sludge amended soil. Soil Biol. Biochem. 21. 327. 
RedDy, G. B., FAZA, A. \& BENNETT, R. JR., 1987. Activity of enzymes in rhizosphere and non-rhizosphere soils amended with sludge. Soil Biol. Biochem. 19. 203-205.

SAstre, I., Vicente, M. A. \& LobO, M. C., 1996. Influence of the application of sewage sludges on soil microbial activity. Bioresource Technol. 57. 19-23.

SEAKER, E. M. \& SOPPER, W. E., 1988. Municipal sludge for minespoil reclamation. I. Effects on microbial populations and activity. J. Environ. Qual. 17. 591-597.

SzEGI J., 1979. Talajmikrobiológiai vizsgálati módszerek. Mezőgazdasági Kiadó. Budapest.

TABatabai, M. A. \& Bremner, J. M., 1969. Use of P-nitrophenol phosphate in assay of soil phosphatase activity. Soil. Biol. Biochem. 1. 301-307.

TABatabai, M. A. \& Bremner, J. M., 1970. Factors affecting soil aryl-sulphate activity. Soil Sci. Soc. Amer. Proc. 34. 427-429.

TSADILAS, C. D. et al., 1995. Influence of sewage sludge application on soil properties and on the distribution and availability of heavy metal fractions. Commun. Soil Sci. Plant Anal. 26. 2603-2619.

VIVAS A. et al., 2004 Fitoremediációs lehetőségek Ni-toleráns mikorrhiza-baktérium növényoltással. In: Mikroelemek a víz-üledék-mikroba-talaj-levegö-növény rendszerben. (Szerk.: SzILÁGYI M. \& SIMON L.) 76-87. Nyírség Nyomda. Nyíregyháza.

World SOIL RESOURCES REPORTS 84, 1998. World Reference Base for Soil Resources. FAO, ISRIC and ISSS-AISS-IBG, Rome.

Érkezett: 2005. március 21. 


\title{
Effect of Sewage Sludge Treatment on the Growth of a Dry Edible Bean Variety (Phaseolus vulgaris L.) and on Microbial Changes in its Rhizosphere
}

\author{
${ }^{1}$ ABDORHIM HAMED, ${ }^{1}$ BAYOUMI HAMUDA E. A. F. HOSAM, ${ }^{1}$ KHALIF A. \\ ABDOUSSALAM, ${ }^{2} \mathrm{~B}$. OLDAL, ${ }^{1} \mathrm{M}$. KECSKÉS and ${ }^{1} \mathrm{G}$. HELTAI
}

\begin{abstract}
${ }^{1}$ Postgraduate School of Environmental Studies, Szent István University, Gödöllő-Budapest and ${ }^{2}$ Research Institute for Soil Science and Agricultural Chemistry of the Hungarian Academy of Sciences, Budapest
\end{abstract}

\section{Summary}

Plants of the resistant Albamax variety of dry bean (Phaseolus vulgaris L.) were grown in a model greenhouse experiment on soil cultures containing various ratios of communal sewage sludge. After 50 days of growth the status of the microorganism community in the soil was analyzed using bean as indicator plant.

In all cases sludge addition was found to increase the total germ number compared to the control, especially at sludge contents of over $30 \%$. Bacteria, particularly those of the Gram-negative type, were dominant in the rhizosphere at all the sewage sludge rates, which can be attributed to the presence of numerous fermentative (facultative anaerobe) microorganisms in this group. As the result of sludge treatment there was an increase in redox potential and in the activity of hydrolytic soil enzymes (dehydrogenase, catalase, protease, urease, $\beta$-glucosidase and phosphatase), which was not greatly inhibited by the presence of heavy metals.

Sludge treatment had a beneficial effect on plant development. Especially at higher sludge concentrations $(70-80 \%)$ there was an increase in the shoot-root ratio, i.e. there was an enhanced accumulation of green mass. The short-term application of sewage sludge is thus a useful method for influencing soil fertility and the physical, chemical and biological soil properties.

Table 1. Biomass of the major microbe groups found in the rhizosphere of bean plants grown for 50 days on weakly acidic humous sandy soil treated with sewage sludge. (1) Treatment (sludge quantity, $\mathrm{m} / \mathrm{m} \%$ ). a) $\mathrm{LSD}_{5 \%}$. (2) Mean value $/ \mathrm{g}$ soil. (3) Bacteria. (4) Aerobic spore-forming bacteria. (5) Actinomycetes. (6) Fungi. Note: *: Values significantly different from the control.

Table 2. Activity of major enzymes in the rhizosphere of bean plants grown on weakly acidic humous sandy soil treated with sewage sludge. (1) Treatment (sludge quantity, \%). (2) Dehydrogenase, (3) Catalase, (4) Protease, (5) Urease, (6) Phosphatase, (7) $\beta$-glucosidase activity.

Fig. 1. Relative dry mass of bean plants grown for 50 days on weakly acidic humous sandy soil treated with sewage sludge; vertical lines indicate LSD $(P \leq 0.05)=21.63$. Horizontal axis: sludge-soil ratio, \%.

Fig. 2. Stem/root ratio of bean plants grown for 50 days on weakly acidic humous sandy soil treated with sewage sludge; $\operatorname{LSD}(\mathrm{P} \leq 0.05)=0.77$. Horizontal axis: see Fig. 1. 